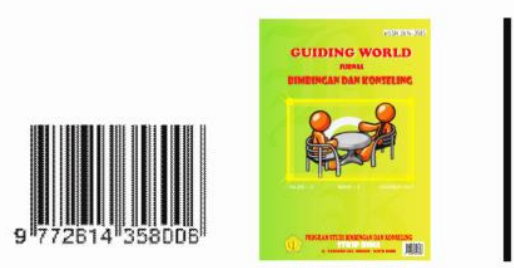

DOI: 1033627

Volume 2 Nomor 2

November 2019

E-ISSN : 2614-3585

\title{
Efektifitas Penggunaan Handphone dalam Meningkatkan Minat Berkonsultasi Siswa SMP (Studi Kasus di SMP Negeri 2 Belo)
}

\author{
Khairunnisa, Sulistia Indah, Alya Nurmaya \\ STKIP Bima \\ e-mail: khairunnisa.hum@gmail.com, sulistia_indah@yahoo.co.id, \\ alyabinsyeikhabubakar@gmail.com
}

\begin{abstract}
Abstrak
Pelaksanaan layanan bimbingan dan konseling dewasa ini selayaknya berlangsung dalam kondisi yang nyaman dan kondusif. Bimbingan dan konseling diharapkan dapat mengembangkan potensi dan juga kompetensi seseorang dalam masyarakat untuk mampu memenuhi tugasnya secara optimal. Selain itu untuk membantu individu dalam mengatasi berbagai masalah yang dapat mengganggu perkembangannya, ${ }^{[1]}$ Penelitian ini dilatar belakangi oleh banyak siswa yang merasa takut jika dipanggil guru BK, apalagi harus datang ke ruang BK untuk berkonsultasi atau sekedar sharing. Rendahnya minat berkonsultasi siswa ini diduga karena berbagai faktor. Salah satunya karena kurangnya sosialisasi yang dilakukan guru BK dalam mengenalkan apa dan bagaimana BK tersebut. Jika sosialisasi ini dapat dilakukan dengan baik, minimal akan memberikan gambaran yang jelas pada siswa bahwa BK hadir sebagai wadah dan teman siswa saat belajar. Upaya-upaya yang bisa dilakukan antara lain seperti: Mampu mengakrabkan diri dengan siswa dan bisa menempatkan diri sebagai teman, serta meningkatkan keterampilan konseling agar dapat meningkatkan keterampilan komunikasi verbal dan non verbal, mengungkap masalah, memahami masalah dan menerima siswa. Agar upaya-upaya tersebut maksimal maka guru BK dapat menggunakan media sebagai alat bantu, salah satunya dapat melalui bantuan media yaitu handphone. Untuk menghilangkan perasaan tersebut maka guru BK menggunakan media handphone sebagai alat komunikasi untuk berkonsultasi dengan siswa. Penelitian ini bertujuan untuk mengetahui apakah penggunaan handphone efektif dalam meningkatkan minat berkonsultasi siswa SMP NEGERI 2 BELO. Pendekatan yang digunakan dalam penelitian ini adalah penelitian kualitatif yang ditunjukkan untuk mendeskripsikan dan menggambarkan fenomena yang ada yang bersifat ilmiah ${ }^{[2]}$. Sedangkan jenis Penelitian yang digunakan adalah jenis penelitian deskriptif. Penelitian ini dilakukan di SMP NEGERI 2 BELO, Subjek penelitian adalah 2 guru BK dan 5 siswa yang telah menggunakan handphone dalam layanan konsultasi. Metode pengumpulan data dilakukan dengan observasi, wawancara, dan dokumentasi. Analisis data menggunakan deskriptif kualitatif dengan cara menginterprestasikan data-data yang diperoleh. Dari penelitian yang dilakukan menunjukkan bahwa proses penggunaan handphone dalam meningkatkan minat berkonsultasi siswa SMP NEGERI 2 BELO dilaksanakan secara bertahap, dimulai dari tahap persiapan terdiri dari pemilihan media dan sosialsasi, kemudian tahap pelaksanaan terdiri
\end{abstract}




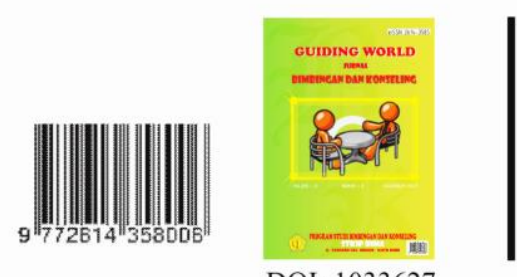

GUIDING WORLD JURNAL BIMBINGAN

DAN KONSELING

Volume 2 Nomor 2

November 2019

E-ISSN : 2614-3585

dari identifikasi, pemberian sosialisasi serta evaluasi baik proses maupun hasil. Berdasarkan hasil penelitian, maka peneliti dapat menyimpulkan bahwa penggunaan handphone efektif dalam meningkatkan minat berkonsultasi siswa SMP Negeri 2 BELO

Kata Kunci : Efektifitas, Minat berkonsultasi siswa, handphone

\begin{abstract}
The implementation of guidance and counseling services should take place in comfortable and conducive conditions. Guidance and counseling is expected to develop one's potential and competence in the community to be able to fulfill their duties optimally. In addition, in helping individuals overcome various problems that can interfere with its development ${ }^{[1]}$. This research is motivated by many students who feel afraid when called by counseling and guididance teachers, let alone have to come to the counseling room to consult or sharing probem. The lack of interest in consulting students was allegedly due to various factors. One of them is due to the lack of socialization conducted by counseling and guidance teachers in introducing what and how counseling and guidance is. If this socialization can be carried out well, it will at least give a clear picture to students that the counseling and guidance is present as a forum and student's friend while studying. Efforts that can be done include: Able to familiarize yourself with students and be able to position yourself as friends, and improve counseling skills so as to improve verbal and non verbal communication skills, express problems, understand problems and accept students. So that these efforts are maximized, the counseling and guidance teacher can use the media as a tool, one of which can be through the help of media, namely mobile phones. To get rid of these feelings, the BK teacher uses mobile media as a communication tool to consult with students. This study aims to determine whether the use of mobile phones is effective in increasing the interest in consulting students of STATE 2ND JUNIOR HIGH SCHOOL. The approach used in this study is qualitative research that is shown to describe and describe existing phenomena that are scientific ${ }^{[2]}$. While the type of research used is descriptive research. This research was conducted in SMP NEGERI 2 BELO, the research subjects were 2 counseling and guidance teachers and 5 students who had used mobile phones in consulting services. The method of data collection is done by observation, interviews, and documentation. Analysis of data using qualitative descriptive by interpreting the data obtained. The research shows that the process of using mobile phones in increasing the interest in consulting students of SMP NEGERI 2 BELO is carried out in stages, starting from the preparation stage consisting of media and socialization selection, then the implementation stage consists of identification, giving outreach and evaluating both the process and the results. Based on the results of the study, the researchers can conclude that the use of mobile phones is effective in increasing the interest in consulting students of SMP Negeri 2 BELO Keywords: Effectiveness, Interest in consulting students, handphone.
\end{abstract}




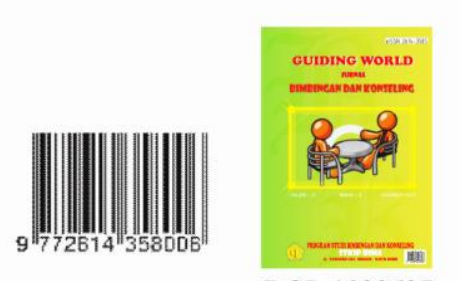

\section{GUIDING WORLD JURNAL BIMBINGAN}

DAN KONSELING

Volume 2 Nomor 2

November 2019

E-ISSN : 2614-3585

DOI: 1033627

\section{Konteks Penelitian}

Pelaksanaan layanan bimbingan dan konseling dewasa ini selayaknya berlangsung dalam kondisi yang nyaman dan kondusif. Terkait adanya paradigma baru dalam bimbingan dan konseling. Paradigma baru itu adalah adanya bimbingan dan konseling diharapkan dapat mengembangkan potensi dan juga kompetensi seseorang dalam masyarakat untuk mampu memenuhi tugasnya secara optimal. Selain itu untuk membantu individu dalam mengatasi berbagai masalah yang dapat mengganggu perkembangannya ${ }^{[1]}$

Bimbingan dan konseling mulai memiliki wajah baru, bukan lagi sebagai polisi sekolah yang hanya menangani siswa bermasalah. Tetapi kenyataannya sangat sulit untuk menjadikan layanan bimbingan dan konseling sebagai media pengembangan diri siswa, dengan menjadikan guru BK sebagai sahabat dalam belajar dan mengembangkan diri. Siswa merasa takut jika dipanggil guru BK, apalagi Jika harus datang ke ruang BK untuk berkonsultasi atau sekedar sharing. Kesan bahwa siswa yang dipanggil adalah mereka yang dianggap memiliki masalah merupakan sesuatu yang sulit di hapuskan.

Beberapa hasil penelitian juga menunjukkan bahwa, minat berkonsultasi siswa itu cenderung rendah. Seperti penelitian yang dilakukan Kumiyati ${ }^{[3]}$ terhadap siswa di SMA Wijaya Putra menemukan bahwa siswa malas untuk berkonsultasi karena akan dicap sebagai siswa yang bermasalah. Sedangkan dalam penelitian Sugiyatno ${ }^{[4]} d i$ SMA Muhammadiyah 2 Yogyakarta minat siswa rendah untuk berkonsultasi dikarenakan kurangnya pemahaman siswa terhadap eksistensi guru pembimbing. Terkait rendahnya minat berkonsultasi siswa juga terjadi di SMP Negeri 2 Belo. Minat siswa untuk berkonsultasi masih rendah, siswa datang berkonsultasi ke guru BK hanya saat dipanggil saja atau saat akan menentukan pilihan Sekolah Menengah Atas (SMA) mereka.

Rendahnya minat berkonsultasi siswa ini diduga karena berbagai faktor. Salah 


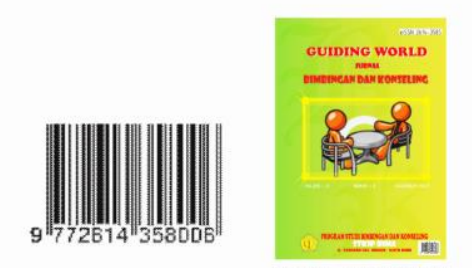

GUIDING WORLD JURNAL BIMBINGAN

DAN KONSELING

Volume 2 Nomor 2

November 2019

E-ISSN : 2614-3585

DOI: 1033627

satunya karena kurangnya sosialisasi yang dilakukan guru BK dalam mengenalkan apa dan bagaimana BK tersebut. Jika sosialisasi ini dapat dilakukan dengan baik, minimal akan memberikan gambaran yang jelas pada siswa bahwa BK hadir sebagai wadah dan teman siswa saat belajar. Layanan bimbingan dan konseling sebagai salah satu bidang tugas di sekolah dituntut untuk dapat dilakukan secara optimal sesuai dengan Undang- Undang No 14 Tahun 2005 di atas. Serta disatu sisi, hal ini juga menjadi tuntutan profesionalisme guru BK sendiri dalam memberikan layanan agar diperoleh hasil yang optimal. Hal lainnya yang ada kaitannya dengan minat untuk berkonsultasi adalah sosok guru BK itu sendiri. Guru BK selain kompetensinya baik, juga dituntut untuk kreatif dan inovatif. Terutama dalam hal menarik minat siswa untuk berkonsultasi.

Upaya-upaya yang bisa dilakukan antara lain seperti : Mampu mengakrabkan diri dengan siswa dan bisa menempatkan diri sebagai teman, serta meningkatkan keterampilan konseling agar dapat meningkatkan keterampilan komunikasi verbal dan non verbal, mengungkap masalah, memahami masalah dan menerima siswa. Agar upaya-upaya tersebut maksimal maka guru BK dapat menggunakan media sebagai alat bantu, salah satunya dapat melalui bantuan media yaitu handphone.

handphone (telepon genggam) adalah perangkat telekomunikasi elektronik yang mempunyai kemampuan dasar yang sama dengan telepon konvesional saluran tetap, namun dapat dibawa kemana-mana (portabel/mobile) dan tidak perlu disambungkan dengan jaringan telepon menggunakan kabel (nirkabel wireless).

Munculnya permasalahan siswa baik pribadi, sosial, sekolah, akan mendorong siswa untuk berkonsultasi dengan guru BK yang ada di sekolah tersebut. Konsultasi ini dapat dilakukan secara langsung maupun tidak langsung, konsultasi secara tidak langsung dapat dilakukan dengan pemanfaatan media atau alat misalnya handphone. Berdasarkan hasil wawancara peneliti dengan beberapa siswa tentang masalah mereka tidak mau konsultasi bahwa siswa kurang percaya diri, malu dan takut untuk berkonsultasi langsung dengan guru BK sehingga siswa kurang berminat untuk 
Volume 2 Nomor 2

November 2019

E-ISSN : 2614-3585

berkonsultasi secara langsung. Untuk menghilangkan perasaan tersebut maka guru BK menggunakan media handphone sebagai alat komunikasi untuk berkonsultasi dengan siswa. Berdasarkan penelitian hampir semua siswa di SMP Negeri 2 Belo memiliki handphone. Oleh sebab itu peneliti ingin mencoba untuk memanfaatkan handphone agar terjalin hubungan yang lebih baik antara guru BK dan siswa sehingga bisa menarik minat berkonsultasi siswa.

\section{Kajian Teori}

\section{a. Penggunaan Handphone}

Handphone (telepon genggam) adalah perangkat telekomunikasi elektronik yang mempunyai kemampuan dasar yang sama dengan telepon konvesional saluran tetap, namun dapat dibawa kemana-mana (portabel/mobile) dan tidak perlu disambungkan dengan jaringan telepon menggunakan kabel (nirkabel wireless). Handphone dilengkapi dengan fitur-fitur yang mudah di mengerti oleh penggunanya, sehingga dapat mempermudah dipakai untuk komunikasi, serta dapat dipakai untuk mendengarkan musik, dan bahkan dapat juga dipakai untuk merekam gambar seperti sebuah kamera atau handyca.

Adapun beberapa manfaat handphone dalam bimbingan dan konseling yaitu untuk mempermudah berkomunikasi antara siswa dan guru BK baik jarak dekat maupun jarak jauh. Di samping sebagai alat komunikasi handphone dapat berfungsi untuk mempererat hubungan antara guru BK dan siswa baik disekolah maupun diluar sekolah. Guru BK dapat menggunakan handphone sebagai alat bantu untuk dapat menarik minat siswa berkonsultasi dengan cara tidak langsung sehingga siswa tidak merasa canggung saat berkonsultasi. Handphone juga dapat dijadikan sarana untuk menambah pengetahuan siswa tentang kemajuan teknologi sehingga siswa tidak dikatakan menutup mata akan kemajuan di era globalisasi saat ini.

\section{b. Minat Berkonsultasi.}




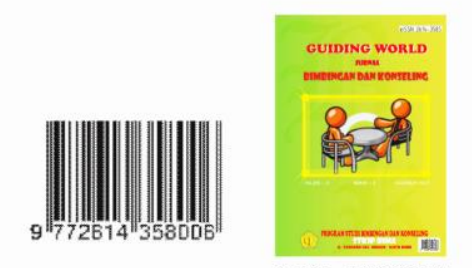

GUIDING WORLD JURNAL BIMBINGAN

DAN KONSELING

Volume 2 Nomor 2

November 2019

E-ISSN : 2614-3585

Minat adalah penerimaan akan suatu hubungan antara diri sendiri dengan sesuatu di luar diri. Semakin kuat atau dekat hubungan tersebut, semakin besar minatnya ${ }^{[5]}$. Pendapat lain mengatakan bahwa minat adalah suatu kecenderungan untuk selalu memperhatikan dan mengingat sesuatu secara terus menerus, Minat ini erat kaitannya dengan perasaan terutama perasaan senang ${ }^{[6]}$. Di samping itu Minat adalah sumber motivasi yang mendorong orang untuk melakukan apa yang mereka inginkan bila mereka bebas memilih ${ }^{[7]}$.

Berdasarkan uraian di atas dapat disimpulkan bahwa minat adalah kesadaran dalam diri seseorang siswa yang merasa tertarik untuk melakukan sesuatu. Berawal dari rasa ketertarikan tersebut akan menjadikan seseorang senang melakukan segala sesuatu yang menarik perhatiannya sehingga menimbulkan minat. Bila seseorang berminat terhadap sesuatu objek atau aktivitas tertentu, maka dapat dikatakan bahwa seseorang menyadari dirinya suka terhadap objek atau aktivitas tersebut, sehingga dalam dirinya timbul perhatian dan rasa senang terhadap objek tersebut.

Dalam Kamus Besar Bahasa Indonesia kata konsultasi diartikan sebagai pertukaran pikiran untuk mendapatkan kesimpulan yang sebaik- baiknya. Sedangkan berkonsultasi diartikan sebagai bertukar pikiran atau meminta pertimbangan dalam memutuskan sesuatu, meminta nasihat. Konsultasi adalah proses yang dilaksanakan teratur oleh manajemen untuk mendapatkan pandangan-pandangan, gagasan dan aspirasi-aspirasi, sebelum mengambil sebuah keputusan ${ }^{[8]}$. Berdasarkan uraian di atas dapat disimpulkan bahwa minat berkonsultasi, adalah kesadaran dalam diri seseorang siswa yang merasa tertarik untuk melakukan sesuatu dengan cara saling bertukar pikiran antara konselor atau guru BK dengan siswa sebagai proses memandirikan konseli sehingga mampu menghadapi pihak ketiga yang dipermasalahkannya.

\section{c. Faktor-Faktor Yang Mempengaruhi Minat Berkonsultasi.}

Dalam kegiatan berkonsultasi setidaknya siswa mempunyai keinginan untuk memecahkan masalah sehingga dapat mencapai hasil yang maksimal. Dengan kehadiran faktor-faktor psikologi akan memberikan andil yang cukup penting karena 
Volume 2 Nomor 2

November 2019

E-ISSN : 2614-3585

faktor psikologis akan senatiasa memberikan landasan dan kemudahan dalam upaya mencapai tujuan yang optimal.

Adapun faktor-faktor yang mempengaruhi minat berkonsultasi adalah :

1. Kebutuhan

Kebutuhan timbul dari dalam diri seseorang apabila seseorang merasa ada kekurangan dalam dirinya. Dalam pengertian homeostatik kebutuhan timbul atau diciptakan apabila dirasakan adanya ketidakseimbangan antara apa yang dimiliki dengan apa yang seharusnya dimiliki

2. Minat atau Kemauan

Siswa mempunyai kecenderungan yang asasi untuk menghubungkan diri dengan lingkungannya melalui cara-cara tertentu. Jika siswa melihat suatu objek maka siswa menaruh minat pada objek tersebut.

3. Aspirasi atau cita-cita

Setiap siswa dalam segala melakukan aktivitasnya mempunyai arah dan tujuan yang akan dicapai. Cita-cita membuat seseorang untuk lebih terarah dalam melaksanakan aktivitasnya, karena dapat terpenuhi apa yang diinginkan dari aktivitas tersebut.

Menurut Gerunga bahwa Faktor-faktor yang mempengaruhi minat berkonsultasi dibedakan menjadi dua yaitu faktor internal dan faktor eksternal ${ }^{[1]}$.

Faktor internal yang terdiri dari motif, perhatian, perasaan dan prestasi sebagai berikut:

1) Motif.

Motif manusia merupakan dorongan, keinginan, hasrat, dan tenaga penggerak lainnya yang berasal dari dalam dirinya, untuk melakukan sesuatu yang terarah pada tujuan.orangtua dalam mendidik anak harus berusaha untuk menggunakan potensipotensinya secara konstruktif dan produktif, yang termasuk di antaranya adalah merangsang minat siswa berkonsultasi.

2) Perhatian. 

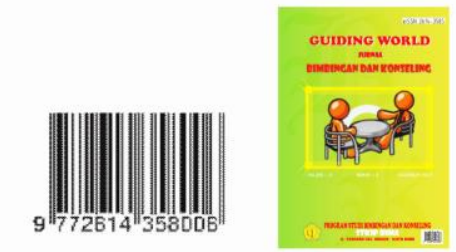

DOI: 1033627

GUIDING WORLD JURNAL BIMBINGAN

DAN KONSELING

Volume 2 Nomor 2

November 2019

E-ISSN : 2614-3585

Perhatian merupakan dasar dari minat. Perhatian didefinisikan sebagai pemfokusan kesadaran, atau dapat juga dikatakan sebagai pemahaman kesadaran. Terdapat dua jenis perhatian, yang pertama adalah perhatian yang diarahkan dalam konsep mental, dan yang kedua perhatian diarahkan ke benda-benda di luar diri. Minat siswa dalam berkonsultasi merupakan jenis perhatian diarahkan dan termasuk dalam golongan perhatian disengaja, karena dalam permasalahan minat ini siswa berkonsultasi dengan kemauan dan kesungguhan hati dalam pencapaian tujuannya.

3) Perasaan.

Merupakan aktivitas psikis yang didalam subjeknya menghayati nilai-nilai suatu objek. Berkaitan dengan perasaan terdapat urutan dalam mencapai minat yaitu adanya perasaan senang disertai sikap positif yang akan menimbulkan minat. Perasaan senang akan menimbulkan minat yang akan diperkuat sikap positif, sebab perasaan merupakan reaksi kejiwaan terhadap perangsang yang dialami orang antara individu satu dengan individu lainnya tidak sama.

\section{4) Prestasi}

Merupakan bukti keberhasilan usaha yang dicapai seseorang setelah memperoleh pengalaman belajar atau mempelajari sesuatu. Seseorang mengalami perubahan tingkah laku secara menyeluruh kemudian perubahan tingkah laku tersebut dapat dinyatakan dengan simbol, maka orang tersebut telah memperoleh prestasi belajar.

Sedangkan faktor yang kedua adalah faktor eksternal yaitu faktor lingkungan dan latar belakang keluarga. Lingkungan dan latar belakang keluarga yang mempengaruhi minat anak. Lingkungan keluarga adalah lingkungan dimana anak berkumpul dengan ayah, ibu, dan saudara- saudaranya. Lingkungan keluarga merupakan lingkungan pertama dan utama dalam proses pendidikan, karena keluarga bertugas untuk meletakkan dasar-dasar pertama pada pertumbuhan, perkembangan, dan pendidikan bagi anak. Melalui pendidikan di tengah keluarga, dependensi/ketergantungan mutlak anak bergeser setahap demi setahap ke arah kebebasan kemanusiaan yang bertanggung jawab di tengah masyarakat, dengan bertambah unsur kemandiriannya. 
Volume 2 Nomor 2

November 2019

E-ISSN : 2614-3585

Berdasarkan beberapa pendapat para ahli di atas dapat disimpulkan bahwa faktorfaktor yang mempengaruhi minat berkonsultasi dipengaruhi oleh dua hal yaitu faktor internal di antaranya kebutuhan, perasaan, motif serta cita-cita atau prestasi. Sedangkan faktor eksternalnya yaitu lingkungan dan latar belakang keluarga.

\section{Metode Penelitian}

\section{a. Pendekatan dan Jenis Penelitian}

Pendekatan yang digunakan dalam penelitian ini adalah penelitian lapangan (field research) dengan pendekatan kualitatif.

Dalam hal ini berkaitan dengan informasi Efektifitas penggunaan handphone dalam meningkatkan minat berkonsultasi di SMP Negeri 2 Belo. Jenis penelitian yang digunakan adalah menggunakan penelitian deskriptif yaitu dengan cara menginterprestasikan data-data yang diperoleh

\section{b. Sumber Data}

Dalam penelitian ini sumber data peneliti yaitu 2 orang guru Bimbingan dan Konseling serta 5 orang siswa. Selain itu peneliti juga menggunakan data sejunder berupa hasil dokumentasi dari pihak sekolah berupa absensi, nilai dan daftar riwayat bimbingan siswa.

\section{c. Metode Pengumpulan data}

Dalam penelitian ini peneliti menggunakan metode observasi, wawancara dan dokumentasi dalam menggali informasi dari sumber data.

\section{d. Metode Analisis data}

\section{Reduksi Data (Data Reduction)}

Reduksi data berarti merangkum, memilih hal-hal yang pokok, memfokuskan pada hal-hal yang penting, dicari tema dan polanya dan membuang yang tidak perlu. Adapun data-data yang peneliti reduksi dengan penelitian antara lain hasil wawancara dan dokumentasi.

\section{Penyajian Data (Data Display)}


Volume 2 Nomor 2

November 2019

E-ISSN : 2614-3585

Setelah data direduksi, maka langkah selanjutnya adalah penyajian data. Dalam penelitian kualitatif, penyajian data bisa dilakukan dalam bentuk uraian singkat, bagan, hubungan antar kategori, lowchart dan sejenisnya. Hal ini paling sering digunakan untuk menyajikan data dalam penelitian kualitatif adalah dengan teks yang bersifat naratif. Adapun data-data yang akan peneliti sajikan adalah efektifitas penggunaan handphone dalam meningkatkan minat berkonsultasi siswa SMP Negeri 2 Belo.

\section{Penarikan Kesimpulan (Verification)}

Langkah ke tiga adalah penarikan kesimpulan dan verifikasi. Kesimpulan awal yang dikemukakan masih bersifat sementara dan bahkan berubah bila tidak ditemukan bukti- bukti yang kuat yang mendukung pada tahap pengumpulan data berikutnya. Tetapi bila kesimpulan yang dikemukakan pada tahap awal didukung oleh bukti yang valid dan konsisten maka merupakan kesimpulan yang kredibel.

\section{e. Metode Keabsahan Data}

Uji keabsahan data dalam penelitian kualitatif meliputi uji credibility (validitas internal), transferability (validitas eksternal), dependability (reliabilitas), confirmability (objektivitas). Namun uji keabsahan data dalam penelitian sering hanya ditekankan pada uji reliabilitas dan validitas saja.

Uji realibilitas berkenaan dengan derajat konsistensi dan stabilitas data. Sedangkan uji validitas atau kreadibilitas merupakan pengujian data. Untuk menguji kreadibilitas data, dalam penelitian ini peneliti menggunakan teknik triangulasi. Triangulasi adalah teknik pemeriksaan keabsahan data yang memanfaatkan sesuatu yang lain diluar data untuk keperluan pengecekan atau sebagai pembanding terhadap data itu ${ }^{[9]}$

Teknik triangulasi yang peneliti gunakan adalah triangulasi sumber, yaitu memanfaatkan sesuatu yang lain dengan membandingkan dan mengecek balik 
Volume 2 Nomor 2

November 2019

E-ISSN : 2614-3585

derajat kepercayaan suatu informasi hasil data yang diperoleh. Adapun langkahlangkah penggunaan teknik triangulasi pada penelitian ini adalah sebagai berikut:

1. Membandingkan data hasil pengamatan atau observasi dengan hasil wawancara.

2. Membandingkan data hasil wawancara antara satu sumber dengan sumber lain.

3. Membandingkan hasil wawancara dengan analisis dokumentasi yang berkaitan

\section{Temuan Penelitian}

Dari hasil wawancara dengan informan serta pengamatan yang dilakukan peneliti, maka peneliti selanjutnya akan mengungkapkan hasil temuan dilapangan.

\section{a. Hasil observasi}

Dalam penelitian ini metode observasi yang digunakan adalah partisipasi pasif (passive participation), dari hasil observasi yang peneliti peroleh bahwa pelaksanaan layanan konsultasi di SMP Negeri 2 Belo belum sepenuhnya terlaksana, dikarenakan kurangnya minat siswa untuk berkonsultasi dengan guru BK. Siswa merasa kurang percaya diri, malu dan takut untuk menceritakan masalah yang dialami apalagi harus bertemu langsung dengan guru BK yang ada di SMP Negeri 2 Belo.

Dari data hasil observasi di atas dapat dimaknai bahwa layanan konsultasi di SMP Negeri 2 Belo kurang terlaksana dikarenakan kurangnya minat siswa untuk berkonsultasi. Untuk itu peneliti mencoba melakukan penelitian tentang efektifitas penggunaan handphone dalam meningkatkan minat berkonsultasi siswa.

Selanjutnya peneliti melakukan observasi tentang layanan konsultasi menggunakan handphone di SMP Negeri 2 Belo. Dalam penelitian ini peneliti melihat bahwa siswa berkonsultasi dengan menggunakan handphone minatnya sangat besar, karena siswa merasa penggunaan media handphone 
Volume 2 Nomor 2

November 2019

E-ISSN : 2614-3585

dalam melakukan layanan konsultasi dapat mempermudah terjalinnya komunikasi antara guru BK dan siswa, sehingga siswa memiliki rasa percaya diri untuk berkonsultasi lebih lanjut.

Dari data hasil observasi menggunakan handphone diatas dapat dimaknai bahwa siswa sangat berminat berkonsultasi menggunakan handphone, karena dirasa dapat mempermudah terjalinnya komunikasi antara guru BK dan siswa.

Dalam penggunaan handphone ini dirasa sangat efektif bagi siswa dan guru BK, untuk itu peneliti mencoba melakukan wawancara dengan guru BK dan siswa yang ada di SMP Negeri 2 Belo.

\section{b. Hasil Wawancara}

\section{a. Hasil Wawancara Dengan Guru BK}

Wawancara pertama yang dilakukan peneliti adalah mewawancarai Guru BK yang ada disekolah SMPN 2 BELO. Wawancara pertama dilakukan pada hari Senin jam 08:45 WITA diruangan BK SMPN 2 Belo. Wawancara kedua dilakukan pada hari Selasa jam 08:45 WITA diruangan BK. Peneliti melakukan wawancara kepada 2 orang guru BK yaitu Bapak Ridwan, S.Pd dan Ibu Sri Ratnasari, S.Pd.

1) Wawancara tentang penggunaan handphone mempermudah layanan komunikasi guru BK dan siswa.

Adapun hasil wawancara dengan Bapak Ridwan yang diperoleh peneliti yaitu :

Untuk penggunaan handphone sendiri sangat membantu mempermudah terjalinya komunikasi antara guru BK dan siswa sehingga siswa tidak merasa canggung untuk berkonsultasi.

Wawancara selanjutnya dilakukan dengan ibu Sri Ratnasari, hasil wawancara diuraikan sebagai berikut: 
DOI: 1033627

Volume 2 Nomor 2

November 2019

E-ISSN : 2614-3585

Handphone sangat mempermudah terjalinya komunikasi antara guru BK dan siswa, sehingga handphone dirasa sangat efektif membantu terjalinnya suatu hubungan yang baik.

Dari jawaban kedua informan di atas dapat dimaknai bahwa penggunaan handphone dapat mempermudah terjalinya komunikasi antara guru BK dan siswa dan sangat efektif sebagai sarana konsultasi.

2) Wawancara tentang Handphone mempererat hubungan guru BK dan siswa, di sekolah maupun diluar sekolah.

Adapun hasil wawancara dengan bapak Ridwan yang diperoleh peneliti yaitu :

Iya memang penggunaan handphone ini sangat membantu sekali, dimana kita sebagai guru BK dapat mengontrol keadaan siswa dimanapun dengan sesekali melalui sms atapun telepon. Setiap tahun ajaran baru kita selalu memberikan nomor Hp ke siswa.

Wawancara selanjutnya dilakukan dengan ibu Sri Ratnasari, hasil wawancara diuraikan sebagai berikut:

Dengan penggunaan handpone disini sangat membantu sekali, guru BK dan siswa menjadi sangat akrab satu sama lain. Dan kita memberikan nomor Hp diawal tahun ajaran baru.

Dari jawaban kedua informan diatas dapat dimaknai bahwa dengan penggunaan handphone ini membantu mempererat hubungan guru BK dan siswa, dan setiap tahun ajaran baru guru BK mensharenka nomor Hp.

3) Wawancara tentang Penggunaan handphone untuk meningkatkan minat berkonsultasi siswa.

Adapun hasil wawancara dengan bapak Ridwan yang diperoleh peneliti yaitu : 
DOI: 1033627

Volume 2 Nomor 2

November 2019

E-ISSN : 2614-3585

Disini kita menggunakan handphone untuk menarik siswa berkonsultasi, karena jarang sekali siswa yang ingin berkonsultasi itu minatnya sangat kurang sehingga kita guru BK memanfaatkan handphone itu sendiri.

Wawancara selanjutnya dilakukan dengan ibu Sri Ratnasari, hasil wawancara diuraikan sebagai berikut:

Kita menggunakan handphone memang untuk menarik minat siswa berkonsultasi, karena yang kita tahu handphone sangat akrab dengan kehidupan siswa sehingga kita memanfaatkan handphone sebagai sarana untuk berkonsultasi.

Dari jawaban kedua informan diatas dapat dimaknai bahwa penggunaan handphone disini untuk dapat menarik minat siswa berkonsultasi karena handphone sangat akrab dengan siswa.

4) Wawancara tentang Minat siswa dalam melakukan layanan konsultasi melalaui handphone.

Adapun hasil wawancara dengan bapak Ridwan yang diperoleh peneliti yaitu :

Minat siswa berkonsultasi dengan menggunakan media handphone sangat membantu sekali, karena siswa bisa berkonsultasi kapan saja dan dimana saja tanpa harus bertatap muka secara langsung.

Wawancara selanjutnya dilakukan dengan ibu Sri Ratnasari, hasil wawancara diuraikan sebagai berikut:

Siswa sangat antusias menjadikan handphone sebagai media untuk berkonsultasi, karena dengan begitu siswa tidak harus bertemu secara langsung, karena kebanyakan siswa merasa canggung jika langsung bertemu.

Dari jawaban kedua informan diatas dapat dimaknai bahwa guru BK menggunakan handphone sebagai media konsultasi untuk dapat 
Volume 2 Nomor 2

November 2019

E-ISSN : 2614-3585

menarik minat siswa sehingga mengefektifkan layanan konsultasi, sehingga tidak harus bertemu seca langsung.

5) Wawancara tentang penggunaan handphone sebagai media layanan konsultasi.

Adapun hasil wawancara dengan bapak Ridwan yang diperoleh peneliti yaitu :

Untuk media handphone sendiri memang kami menggunakannya, karena demi kelancaran layanan konsultasi dengan siswa.

Wawancara selanjutnya dilakukan dengan ibu Sri Ratnasari, hasil wawancara diuraikan sebagai berikut:

Kami menggunakan media handphone sebagai media untuk berkonsultasi karena media itu sangat dekat dan sering digunakan oleh siswa, disitu kami memanfaatkan salah satu media yang sangat akrab dengan siswa.

Dari jawaban kedua informan diatas dapat dimaknai bahwa penggunaan handphone sebagai media layanan konsultasi dapat membantu melancarkan layanan konsultasi.

6) Wawancara tentang Tertarik melakukan konsultasi.

Adapun hasil wawancara dengan bapak Ridwan yang diperoleh peneliti yaitu :

\section{Kebanyakan dari siswa kurang tertarik berkonsultasi dengan guru BK.}

Wawancara selanjutnya dilakukan dengan ibu Sri Ratnasari, hasil wawancara diuraikan sebagai berikut:

15 
DOI: 1033627

Volume 2 Nomor 2

November 2019

E-ISSN : 2614-3585

Siswa tidak terlalu tertarik untuk berkonsultasi, sehingga kita sebagai guru BK harus benar-benar bisa menarik minat siswa untuk berkonsultasi.

Dari jawaban kedua informan diatas dapat dimaknai bahwa siswa kurang tertarik melakukan konsultasi dengan guru BK

7) Wawancara tentang Kesadaran untuk berkonsultasi.

Adapun hasil wawancara dengan bapak Ridwan yang diperoleh peneliti yaitu :

Walaupun banyak masalah yang dihadapi setiap siswa, terkadang siswa tidak sadar dan mengabaikannya begitu saja sehingga masalah yang dihadapi semakin mempersulit mereka juga.

Wawancara selanjutnya dilakukan dengan ibu Sri Ratnasari, hasil wawancara diuraikan sebagai berikut:

Karena kurangnya minat berkonsultasi, siswa tidak sadar bahwa berkonsultasi dengan guru BK itu bisa sangat membantu untuk keluar dari permasalahan yang sedang dihadapi. Tetapi siswa tidak ada kesadaran untuk berkonsultasi.

Dari jawaban kedua informan diatas dapat dimaknai bahwa tidak adanya kesadaran dalam diri siswa untuk berkonsultasi dengan guru BK.

\section{b. Hasil Wawancara Dengan Siswa}

Peneliti melakukan wawancara kepada 5 orang siswa yaitu Siswa 1, Siswa 2, Siswa 3, Siswa 4 dan Siswa 5. Wawancara dilakukan pada hari Rabu, Kamis dan Sabtu pada jam yang sama yaitu jam 09:30 Wita diruangan BK SMPN 2 Belo.

1) Wawancara tentang penggunaan handphone mempermudah layanan komunikasi guru BK dan siswa. 


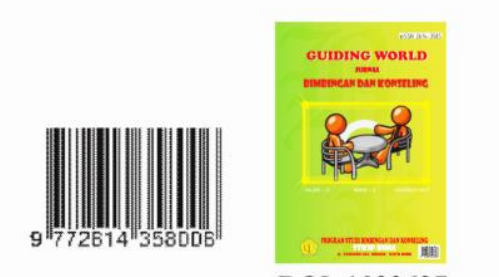

DOI: 1033627
GUIDING WORLD JURNAL BIMBINGAN

DAN KONSELING

Volume 2 Nomor 2

November 2019

E-ISSN : 2614-3585

Adapun hasil wawancara dengan siswa 1, siswa 2, siswa 3, siswa 4, dan siswa 5 yang peneliti peroleh dan dirangkum sebagai berikut :

Memang kenyataannya handphone sangat membantu kami sebagai siswa untuk mempermudah komunikasi dengan guru BK.

Dari jawaban yang peneliti peroleh dapat dimaknai bahwa handphone mempermudah layanan komunikasi guru BK dan siswa.

2) Wawancara tentang Handphone mempererat hubungan guru BK dan siswa, di sekolah maupun diluar sekolah.

Adapun hasil wawancara dengan siswa 1, siswa 2, siswa 3, siswa 4, dan siswa 5 yang peneliti peroleh dan dirangkum sebagai berikut:

Kalau dibilang mempererat hubungan memang benar, kami sebagai siswa merasa dengan menggunakan handphone sangat berguna karna adanya hubungan timbal balik antara guru BK dan siswa. Dan guru BK setiap tahun ajaran baru selalu mensharekan nomor Hp-nya.

Dari jawaban yang peneliti peroleh dapat dimaknai bahwa penggunaan handphone sangat bermanfaat untuk mempererat hubungan siswa dan guru BK. Dan mensharekan nomor Hp-nya.

3) Wawancara tentang Penggunaan handphone untuk meningkatkan minat berkonsultasi siswa.

Adapun hasil wawancara dengan siswa 1, siswa 2, siswa 3, siswa 4, dan siswa 5 yang peneliti peroleh dan dirangkum sebagai berikut:

Kalau ditanya minat menggunakan handphone kita sangat senang apalagi handphone sudah sangat akrab dengan kehidupan kita sekarang, sehingga dapat meningkatkan minat berkonsultasi siswa. 
DOI: 1033627

Volume 2 Nomor 2

November 2019

E-ISSN : 2614-3585

Dari jawaban yang peneliti peroleh dapat dimaknai bahwa penggunaan handphone dapat meningkatkan minat berkonsultasi siswa.

4) Wawancara tentang Minat siswa dalam melakukan layanan konsultasi melalaui handphone.

Adapun hasil wawancara dengan siswa 1, siswa 2, siswa 3, siswa 4, dan siswa 5 yang peneliti peroleh dan dirangkum sebagai berikut:

Kita sebagai siswa sangat berminat karena berkonsultasi dengan handphone sangat efektif sehingga tidak harus bertemu langsung dengan guru BK.

Dari jawaban yang peneliti peroleh dapat dimaknai bahwa berkonsultasi dengan handphone siswa sangat berminat.

5) Wawancara tentang penggunaan handphone sebagai media layanan konsultasi.

Adapun hasil wawancara dengan siswa 1 , siswa 2, siswa 3, siswa 4, dan siswa 5 yang peneliti peroleh dan dirangkum sebagai berikut:

Dalam melakukan layanan konsultasi guru BK tidak menggunakan media khusus dalam berkonsultasi, hanya menggunakan handphone dengan melalui sms atau telepon.

Dari jawaban yang peneliti peroleh dapat disimpulkan bahwa tidak adanya penggunaan media khusus yang digunakan oleh guru BK. Melainkan menggunakan handphone.

6) Wawancara tentang Tertarik melakukan konsultasi.

Adapun hasil wawancara dengan siswa 1, siswa 2, siswa 3, siswa 4, dan siswa 5 yang peneliti peroleh dan dirangkum sebagai berikut:

Dibilang tertarik berkonsultasi tidak juga, kita jarang bertemu dengan guru BK apalagi berkonsultasi. 


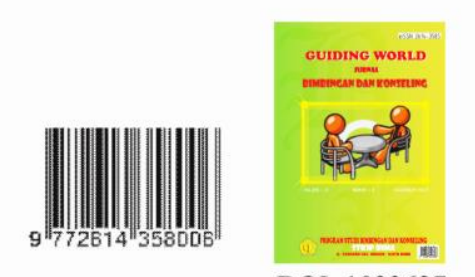

DOI: 1033627

\section{GUIDING WORLD JURNAL BIMBINGAN}

DAN KONSELING

Volume 2 Nomor 2

November 2019

E-ISSN : 2614-3585

Dari jawaban yang peneliti peroleh dapat dimaknai bahwa siswa/siswi di SMPN 2 Belo tidak tertarik untuk berkonsultasi.

7) Wawancara tentang Kesadaran untuk berkonsultasi.

Adapun hasil wawancara dengan siswa 1, siswa 2, siswa 3, siswa 4, dan siswa 5 yang peneliti peroleh dan dirangkum sebagai berikut:

Kita sebagai siswa tidak pernah sadar bahwa berkonsultasi dengan guru BK itu penting, kalaupun kita punya masalah kita abaikan saja dan tidak mengkonsultasikannya dengan guru BK.

Dari jawaban yang peneliti peroleh dapat dimaknai bahwa siswa tidak memiliki kesadaran untuk berkonsultasi dengan guru BK

\section{Pembahasan Hasil Temua}

Berdasarkan dari hasil temuan penelitian pada bagian 4 (empat) diatas dapat diperoleh dari hasil wawancara peneliti dengan guru BK dan siswa bahwa dalam efektifitas penggunaan handphone sebagai media untuk berkonsultasi di SMP Negeri 2 Belo sangatlah efektif, hal ini terlihat dari hasil wawancara guru BK dan siswa yang menyataakan bahwa handphone memiliki peranan penting dalam meningkatkan minat berkonsultasi siswa. Disamping itu, media handphone sangat diminati dikalangan remaja saat ini karena handphone sangat akrab dengan kehidupan seharihari siswa sehingga guru BK dapat memanfaatkan handphone sebagai media untuk melakukan layanan konsultasi terhadap siswa.

Melalui media handphone proses pelaksanaan layanan konsultasi terhadap siswa juga sangat mudah, dimana guru BK memberikan nomor handphone kepada siswa dan sebelum melakukan konsultasi siswa diharapkan dapat mengkonfirmasi terlebih dahulu kepada guru BK, sehingga siswa dapat berkonsultasi dimana saja dan kapan saja tanpa harus bertemu langsung dengan guru BK, karna kebanyakan dari siswa yang kurang percaya diri, malu dan takut untuk datang langsung keruang BK. Dalam 


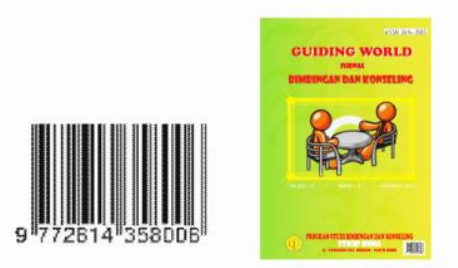

GUIDING WORLD JURNAL BIMBINGAN

DAN KONSELING

Volume 2 Nomor 2

November 2019

E-ISSN : 2614-3585

DOI: 1033627

proses ini di anggap layanan secara tidak langsung karna tidak adanya pertemuan antara guru BK dengan siswa. Dalam proses ini juga sifatnya praktis karna sebelumnya tidak ada perencanaan yang dilakukan dan semuanya berjalan apa adanya tanpa ada persiapan khusus seperti melakukan konsultasi diruangan BK.

Pada layanan konsultasi menggunakan media handphone tidak lepas dari faktor penghambat dan faktor pendukungnya, dimana faktor penghambatnya yaitu pulsa yang banyak keluar dan kadang-kadang handphone juga mudah ngedrop dan hanya bisa menghubungi anak pada saat jam tertentu, jadi apabila siswa ingin berkonsultasi siswa dapat memberitahu guru BK terlebih dahulu dengan melalui sms maupun telepon sehingga guru BK dapat mempersiapkan kebutuhan sebelum melakukan layanan konsultasi. Sedangkan faktor pendukungnya yaitu informasi lebih cepat di dapat dan lebih cepat sampai. Hasil yang dicapai dari layanan konsultasi menggunakan handphone ini yaitu mampu meningkatkan minat siswa ataupun orang tua untuk berkonsultasi dengan guru BK, dimana orang tua bisa mengetahui perkembangan si anak, disamping itu anak akan berhati-hati dalam melakukan perbuatannya dan handphone menjadi lebih efektif sebagai sarana berkomunikasi karena lokasi yang jauh.

Dengan menggunakan media handphone sebagai media untuk berkonsultasi siswa bisa mengerti pentingnya berkonsultasi dengan guru $\mathrm{BK}$, dimana siswa bisa menemukan solusi dari permasalahan yang dialami dan bisa lebih dekat dengan guru BK sehingga siswa dapat menceritakan permasalahannya tanpa harus merasa takut. Ketika berkonsultasi menggunakan handpone siswa sangat berminat sebab media tersebut sangat efektif untuk melakukan layanan konsultasi sehingga siswa tidak perlu bertemu dan datang langsung keruang BK karena siswa merasa kurang percaya diri untuk menceritakan dan berhadapan secara langsung dengan guru BK.

Siswa menggunakan media handphone sebagai media konsultasi karna siswa merasa perlu untuk berkonsultasi sehingga ada umpan balik dari guru BK untuk memberikan masukan terhadap masalah yang dikonsultasikan, dan terkadang siswa 


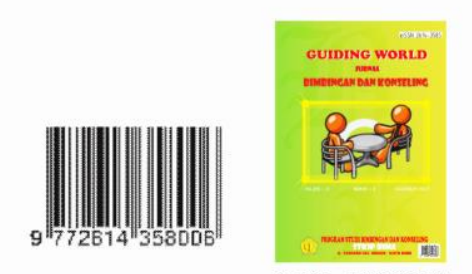

GUIDING WORLD JURNAL BIMBINGAN

DAN KONSELING

Volume 2 Nomor 2

November 2019

E-ISSN : 2614-3585

DOI: 1033627

sangat membutuhkan saran dari orang tua tetapi karena merasa malu siswa berkonsultasi kepada guru BK. Dan biasanya masalah yang dikonsultasikan yaitu seputar masalah yang ada di lingkungan sekolah dan berharap guru BK dapat menemukan solusi yang tepat. Dengan menggunakan handphone permasalahan yang dikonsultasikan dapat diselesaikan dengan baik selain itu juga dapat memberikan dampak positif terhadap guru BK dan siswa sehingga dapat berkomunikasi antara satu sama lain dengan melalui sms ataupun telepon untuk memperlancar konsultasi sehingga terjalin hubungan dan komunikasi lebih baik antara siswa dan guru BK.

Dari hasil penelitian di atas dapat disimpulkan bahwa penggunaan handphone dalam meningkatkan minat berkonsultasi siswa SMP Negeri 2 Belo sangat efektif, dimana dapat dilihat bahwa siswa sangat berminat melakukan layanan konsultasi dengan menggunakan handphone karna dianggap mampu menyelesaikan permasalahan yang dikonsultasikan, serta terjalin hubungan komunikasi yang baik antara siswa dan guru BK. Disamping itu, siswa jadi sangat berani, tidak takut dan malu lagi untuk berkonsultasi dengan guru BK sehingga dapat memberikan dampak positif bagi keduanya

\section{Kesimpulan}

Berdasarkan hasil penelitian, maka peneliti dapat menyimpulkan bahwa penggunaan handphone efektif dalam meningkatkan minat berkonsultasi siswa SMP Negeri 2 Belo. Dalam pelaksanaannya dilakukan secara tiga tahap yaitu persiapan dengan menyiapkan handphone sebagai media atau alat komunikasi yang nantinya akan digunakan dalam proses konsultasi, sosialisasi dengan cara membagikan nomor handphone pada awal tahun ajaran baru. Kemudian tahap pelaksanaan guru BK melakukan identifikasi, menjawab pertanyaan dan memberikan solusi pada siswa. Dan yang terakhir evaluasi dengan melihat proses dan hasil yang diperoleh. Hasil yang di capai dalam penelitian ini yaitu penggunaan handphone dalam meningkatkan minat berkonsultasi siswa SMP sangat efektif dan mempermudah komunikasi antara 
Volume 2 Nomor 2

November 2019

E-ISSN : 2614-3585

siswa dengan guru BK, serta informasi lebih cepat di terima, mampu meningkatkan minat siswa dalam berkonsultasi serta mampu membantu masalah yang dikonsultasikan siswa.

\section{Daftar Rujukan}

[1] Winkel W.S, Bimbingan Konseling di Institusi Pendidikan, (Jakarta:Grasindo, 1997)

[2] Nana Syaodih, S, Metodologi Penelitian Pendidikan, (Bandung: Remaja Rosdakarya, 2005).

[3] Kumiyati, "Penelitian Tindakan Kelas X SMA", http://kumiyati.wordpress.com/27 /02/2015.

[4] Sugiyatno, Upaya Guru PembimbingDalam Meningkatkan Minat Siswa Berkonsultasi dalam“E-Journal.staff-uny.ac.id.”15/03/2015

[5] Djaali, Psikologi Pendidikan (Jakarta: Bumi Aksara, 2008), cet ke-3.

[6] Sofyan S. Willis, Konseling Individual (Teori dan Praktek), (Bandung: CV: Alfabeta, 2004).

[7] Hurlock, Elizabeth. B, Psikologi Perkembangan terj. Istigwiyanti dan Soedjarwo edisi 5, (Inggris : 1980).

[8] Julia Middleton, Konsultasi, (Jakarta: Gunung Mulia, 1997)

[9] Sugiyono, Metode Penelitian Pendidikan Pendekatan Kuantitatif, Kualitatif dan $R \& D$, (Bandung: Alfabeta, 2008). 